\title{
DISPLACEMENT OF NITROGEN FROM NORMAL HUMAN LUNGS DURING OXYGEN BREATHING ${ }^{1}$
}

\author{
By AARON A. COHEN, ALLAN HEMINGWAY, AND CLAIRE HEMINGWAY \\ (From the Veterans Administration Hospital, San Fernando, Calif., and the Department of \\ Physiology, School of Medicine, University of California, Los Angeles, Calif.)
}

(Submitted for publication September 17, 1957; accepted October 4, 1957)

\begin{abstract}
Abnormalities of intrapulmonary distribution and mixing of inspired gases occur in diseases of the lungs, particularly in pulmonary emphysema. Interest in this problem began in 1864, and has been pursued with many different methods (1). However, uncertainty and even confusion still exists not only in the definition but also in the quantitative measurement of intrapulmonary distribution and mixing. One means of investigating the problem is the measurement of nitrogen displacement from the lung as it occurs during oxy-
\end{abstract} gen breathing, reported by Cournand and his associates (2-4). As an index of impaired distribution and mixing of the inspired gas with alveolar gas, they proposed an end-expired nitrogen concentration exceeding 2.5 per cent, delivered by a forced expiration at the end of a seven minute period of quiet oxygen-breathing (3). With such a technique only two points in the course of the nitrogen dilution were known-the initial alveolar nitrogen concentration while breathing air, and the final nitrogen concentration produced by the terminal forced expiration. Subsequently, a mathematical expression was presented (4) for ideal intrapulmonary mixing of oxygen and nitrogen, enabling predictions of the intrapulmonary nitrogen concentration at the end of any given number of breaths of oxygen. Divergence was found even in normal persons between the actual course of nitrogen dilution and the predicted course.

With the help of continuous rapid automatic gas analyzers such as the nitrogen meter (5) and the mass spectrometer (6), later investigators could follow the breath-by-breath dilution of nitrogen during the breathing of oxygen. After graphical analysis of the displacement curves they proposed interesting concepts of well-ventilated and poorly-

1 This work was supported in part by a grant from the Los Angeles County Tuberculosis and Health Association. ventilated lung compartments, and of rates of gas mixing in these spaces (6-8). Simpler criteria were proposed by others (9-13), in particular "turnover indices" which related functional residual capacity to the total ventilation required to dilute the intrapulmonary nitrogen to a given endpoint $(10,12,13)$.

Previous workers have studied relatively few normal human subjects. The purposes of the present paper are to present data on the quantitative aspects of nitrogen displacement from the lungs of fifty normal persons, as a basis of comparison for the findings in patients with pulmonary disease, and to suggest certain clinically valuable criteria for the evaluation of intrapulmonary gas mixing. From this investigation normal nitrogen clearance characteristics have been determined, and the physiological factors which influence clearance have been evaluated.

\section{MATERIAL AND METHODS}

Fifty medical students free from pulmonary disease were selected for study, on the basis of a health questionnaire and review of Student Health Service records, which included recent chest radiographs and physical examinations.

The open-circuit method of Cournand, Baldwin, Darling, and Richards (3) for measurement of functional residual capacity was modified to include continuous monitoring of the expired nitrogen by a nitrogen meter with a recording milliammeter. ${ }^{2}$ The combined accuracy of our nitrogen meter and recording system varied from +0.1 per cent to -0.2 per cent (mean, -0.05 per cent in 51 trials) in the range of 0 to 20 per cent nitrogen, and amounted to \pm 0.5 per cent in the 20 per cent to 80 per cent nitrogen range, as determined by comparison with manometric gas analysis (14). Minimum readability in the 0 to 20 per cent range was 0.1 per cent nitrogen; in the 20 per cent to 80 per cent range it was 0.5 per cent

2 The nitrogen meter was manufactured by the Waters Company, Rochester, Minnesota. The recorder was manufactured by the Esterline-Angus Company, Indianapolis, Indiana. 
nitrogen. The nitrogen meter was calibrated before and after each run with a series of known mixtures of nitrogen and oxygen, bubbled through water.

The subjects, in a nonbasal state, rested for 10 to 15 minutes before being tested. All tests were made in the supine position. Air was breathed by mouthpiece through a four-way respiratory valve, two arms of which were connected to a balloon-in-bottle system containing air, one arm to a Douglas bag containing oxygen, and one arm to a 120 liter Tissot spirometer. A spirometer record of the tidal volume changes in the balloon was obtained during air-breathing. When it was apparent that breathing was even and that the expiratory base line was steady, the subject was switched from air to cylinder oxygen exactly at the end of a normal expiration. With this arrangement, a switch made too soon or too late could be corrected in the calculation of functional residual capacity. For the next seven minutes the subject inspired oxygen from the Douglas bag and expired into the Tissot spirometer. The volume of each expiration was recorded on the Tissot kymograph, which was started simultaneously with the nitrogen meter recorder at the instant oxygen-breathing began. The nitrogen meter sampled continuously from a point just distal to an expiratory flap valve near the mouthpiece. Thus, a breath-by-breath analysis of the end-expired nitrogen concentration and expiratory volume was made. At the end of the seventh minute a forced expiration was made and a sample of gas was drawn into a syringe from a point adjacent to the nitrogen meter sampling connection, following which the subject was switched back to air-breathing. The final concentrations of nitrogen and carbon dioxide in the Tissot spirometer were measured by manometric (14) and volumetric (15) methods, as well as by the nitrogen meter. The final forced expiratory sample was analyzed for carbon dioxide. The peak end-expired nitrogen concentration was considered "alveolar" $\left(\mathrm{F}_{\mathrm{A}_{2}}\right)$, as was the carbon dioxide concentration in the final forced expiration $\left(\mathrm{FACO}_{2}\right)$.

The Tissot kymograph record was used to calculate tidal volumes, respiratory rates, and minute ventilation (all volumes in this report are corrected to body temperature and pressure, saturated with water vapor). Functional residual capacity (FRC) was calculated according to the previously described method (3), correcting for diffusion of tissue nitrogen into the alveoli (16). Suitable corrections were made for valve dead space and for deviations from the true expiratory base line when the subject was switched to oxygen. Alveolar ventilation was computed according to a derivation from the Bohr formula (17): $\mathrm{V}_{\mathbf{A}} / \mathrm{V}_{\mathrm{E}}=\mathrm{FECO}_{2} / \mathrm{F}_{\mathrm{AcO}_{2}}$, where $\mathrm{V}_{\mathbf{A}}$ is alveolar ventilation, $V_{E}$ is total expired ventilation, $F_{A C O}$ is alveolar carbon dioxide (vide supra), and $\mathrm{FE}_{\mathrm{CO}_{2}}$ is the volume fraction of carbon dioxide in the mixed expired (spirometer) gas (18). From the record of the nitrogen meter and from the spirometer kymograph record of collected expired gas, a graph was prepared plotting the logarithm of $100\left(\mathrm{~F}_{\mathrm{A}_{N_{2}}}-\mathrm{F}_{\mathrm{I}_{\mathrm{N}_{2}}}\right)$, which is the difference between end-expired nitrogen and inspired nitrogen (usu-

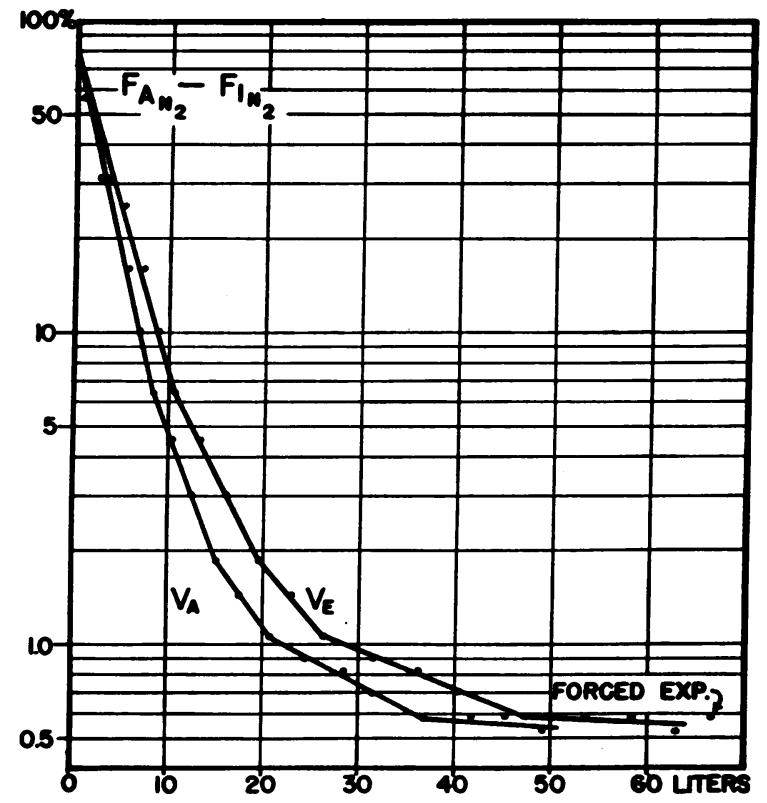

Fig. 1. Graph of Decline in Expired Nitrogen Concentration (End-Tidal) as a Function of Total Expired Gas Volume ( $V_{e}$ ) and of Alveolar Component of Total Expired Gas Volume $\left(\mathrm{V}_{\mathrm{A}}\right)$, During Oxygen Breathing for Seven Minutes

$F_{A_{N_{2}}}-F_{I_{N_{2}}}=$ per cent expired $N_{2}$ minus per cent inspired $\mathrm{N}_{2}$.

ally 0.5 per cent to 0.6 per cent in the cylinder oxygen), expressed as per cent, on the ordinate against total expired volume $\left(\mathrm{V}_{\mathbf{E}}\right)$ or against total alveolar volume $\left(\mathrm{V}_{\mathbf{A}}\right)$ on the abscissa. The points on the graph represent nitrogen-volume values for frequently selected breaths during the entire period of oxygen-breathing. This type of graph, the so-called washout curve, is shown in Figure 1.

\section{RESULTS}

The physical characteristics of the subjects are given in Table I. Also tabulated are the relevant features of their respiration which might affect the rate of nitrogen displacement. The subjects have been divided into three groups. Group $I$ is composed of 33 men whose resting expiratory base line before the change from air-breathing to oxygen-breathing was constant enough to permit confidence in the computed FRC. Their mean FRC was 2.29 liters \pm 0.51 . (S. D.). Group II consists of 12 men whose FRC measurements could not be considered as exact as in Group I because of difficulty in reaching a steady expiratory level in the period of time allowed before the switch to oxygen. They are not included in the evaluation of 
TABLE I

Characteristics of fifty normal young adults

\begin{tabular}{|c|c|c|c|c|c|c|c|c|c|}
\hline Group & Age & Height & Weight & B.S.A.* & FRC* & $\mathrm{f}^{*}$ & $\mathrm{VT}^{*}$ & $\dot{\mathrm{V}}_{\mathrm{E}^{*}}$ & $\mathrm{~V}_{\mathbf{A}} / \mathrm{VE}^{*}$ \\
\hline I 33 males & yrs. & in. & lbs. & $M .^{2}$ & liters & & $m l$. & lilers/min./M.2 & \\
\hline $\begin{array}{l}\text { Mean } \\
\text { S. D. }\end{array}$ & $\begin{array}{r}24.1 \\
2.3\end{array}$ & $\begin{array}{r}70.7 \\
2.7\end{array}$ & $\begin{array}{r}162.7 \\
19.3\end{array}$ & $\begin{array}{l}1.92 \\
0.14\end{array}$ & $\begin{array}{l}2.295 \\
0.512\end{array}$ & $\begin{array}{r}11.0 \\
4.2\end{array}$ & $\begin{array}{l}803 \\
281\end{array}$ & $\begin{array}{l}4.13 \\
0.79\end{array}$ & $\begin{array}{l}0.66 \\
0.08\end{array}$ \\
\hline $\begin{array}{l}\text { II. } 12 \text { males } \\
\text { Mean } \\
\text { S. D. }\end{array}$ & $\begin{array}{r}23.1 \\
1.6\end{array}$ & $\begin{array}{r}71.1 \\
2.4\end{array}$ & $\begin{array}{r}172.3 \\
28.3\end{array}$ & $\begin{array}{l}1.98 \\
0.17\end{array}$ & $\begin{array}{l}2.543 \\
0.373\end{array}$ & $\begin{array}{l}9.7 \\
3.1\end{array}$ & $\begin{array}{l}956 \\
401\end{array}$ & $\begin{array}{l}4.32 \\
0.88\end{array}$ & $\begin{array}{l}0.70 \\
0.08\end{array}$ \\
\hline $\begin{array}{l}\text { III. } 5 \text { females } \\
\text { Mean } \\
\text { S. D. }\end{array}$ & $\begin{array}{r}26.2 \\
7.7\end{array}$ & $\begin{array}{r}65.3 \\
2.9\end{array}$ & $\begin{array}{r}128.6 \\
18.8\end{array}$ & $\begin{array}{l}1.64 \\
0.15\end{array}$ & $\begin{array}{l}1.742 \\
0.302\end{array}$ & $\begin{array}{r}13.5 \\
3.3\end{array}$ & $\begin{array}{r}500 \\
60\end{array}$ & $\begin{array}{l}4.06 \\
0.72\end{array}$ & $\begin{array}{l}0.62 \\
0.06\end{array}$ \\
\hline
\end{tabular}

* B.S.A. = Body surface area, in square meters.

$\mathrm{FRC}=$ Functional residual capacity, in liters.

$\mathrm{f}=$ Number of respirations per minute.

$\mathrm{V}_{\mathrm{T}}=$ Tidal volume, in $\mathrm{ml}$.

$\dot{V}_{\mathbf{E}}=$ Minute volume of expired gas, in liters per square meter B.S.A.

$\mathrm{V}_{\mathrm{A}} / \mathrm{V}_{\mathbf{E}}=$ Alveolar fraction of total expired gas.

the initial or steep part of the nitrogen washout curve, where size of FRC exerts its greatest influence (vide infra). However, their washout behavior in the latter part of the seven minute period is regarded as satisfactory for inclusion with the other subjects because, despite variation of the initial FRC, intrapulmonary mixing should be complete, or almost so, at the end of seven minutes in these normal young individuals. Review of the data showed this assumption to be correct. The data for five females are listed separately in Table I as Group III. Their mean FRC was 1.74 liters \pm 0.30 (S. D.).

The values for, and the variability of, FRC among our subjects confirm the findings of others (19-21) who have measured pulmonary volume compartments in normals (Table II). In agreement with these investigators (19-22), no close correlation was found between FRC and various parameters of body size, including the cube of the height as suggested by Bateman (23).

The ratio $\mathrm{V}_{\mathbf{A}} / \mathrm{V}_{\mathbf{E}}$, which relates total ventilation to alveolar ventilation, depends on $\mathrm{FA}_{\mathrm{CO}_{2}}$ in a single forced expiration and has the inherent errors of dead space determination (24), yet offers the advantages of utility. The mean values in Groups I, II, and III are $0.66,0.70$, and 0.62 , respectively, and are close to the generally accepted normal value of 0.70 (25).

The nitrogen clearance curves are presented for simplicity in two phases-the initial rapid drop of end-expired nitrogen as a function of summated expired ventilation $\left(V_{\mathbf{E}}\right)$ or of summated alveolar ventilation $\left(\mathrm{V}_{\mathbf{A}}\right)$, and the subsequent slow decline. Previous workers $(6,7)$ have attempted, by plotting $\log \mathrm{FE}_{\mathrm{N}_{2}}$ against time or number of breaths

TABLE II

Comparative values for functional residual capacity in literature and in present study

\begin{tabular}{|c|c|c|c|c|c|c|}
\hline Investigators & $\begin{array}{l}\text { No. of } \\
\text { subjects }\end{array}$ & Sex & Age & Posture & Mean FRC & $\begin{array}{l}\text { Variability } \\
\text { of FRC }\end{array}$ \\
\hline Kaltreider (19) & $\begin{array}{l}50 \\
50\end{array}$ & $\begin{array}{l}\mathrm{M} \\
\mathrm{F}\end{array}$ & $\begin{array}{c}y r s . \\
18-30 \\
18-30\end{array}$ & $\begin{array}{l}\text { Supine } \\
\text { Supine }\end{array}$ & $\begin{array}{l}\text { liters } \\
2.18 \\
1.82\end{array}$ & $\begin{array}{l}0.50 \text { (S. D.) } \\
0.39 \text { (S. D.) }\end{array}$ \\
\hline Needham (20) & $\begin{array}{l}27 \\
18\end{array}$ & $\begin{array}{l}\mathrm{M} \\
\mathrm{F}\end{array}$ & $\begin{array}{l}20-30 \\
20-30\end{array}$ & $\begin{array}{l}\text { Seated } \\
\text { Seated }\end{array}$ & $\begin{array}{l}3.21 \\
2.34\end{array}$ & $\begin{array}{l}1.9-4.3 \\
1.7-3.5\end{array}$ \\
\hline Whitfield (21) & $\begin{array}{l}41 \\
16\end{array}$ & $\begin{array}{l}\mathrm{M} \\
\mathrm{F}\end{array}$ & $\begin{array}{l}10-70 \\
10-70\end{array}$ & $\begin{array}{l}\text { Supine } \\
\text { Supine }\end{array}$ & $\begin{array}{l}2.459 \\
1.856\end{array}$ & $\begin{array}{l}0.591 \text { (S. D.) } \\
0.458 \text { (S. D.) }\end{array}$ \\
\hline Present study & $\begin{array}{r}33 \\
5\end{array}$ & $\stackrel{\mathrm{M}}{\mathrm{F}}$ & $\begin{array}{l}21-31 \\
21-38\end{array}$ & $\begin{array}{l}\text { Supine } \\
\text { Supine }\end{array}$ & $\begin{array}{l}2.295 \\
1.742\end{array}$ & $\begin{array}{l}0.512 \text { (S. D.) } \\
0.302 \text { (S. D.) }\end{array}$ \\
\hline
\end{tabular}



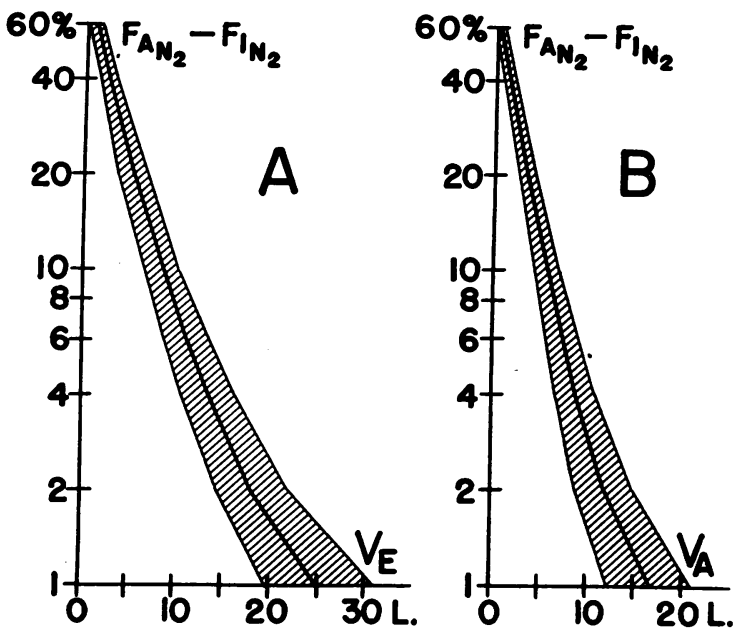

Fig. 2. A-Course of Decline of End-Tidal Nitrogen Concentration to 1 Per Cent as Function of Total Expired Gas Volume, During Oxygen Breathing; B-Same, Relating Decline in Nitrogen ConCentration to Alveolar Ventilation

Heavy central lines represent mean values for Group I (33 subjects). Cross-hatching represents one standard deviation from the mean. $F_{\mathrm{A}_{2}}-\mathrm{F}_{\mathrm{I}_{2}}=$ per cent expired $\mathrm{N}_{2}$ minus per cent inspired $\mathrm{N}_{2}$.

on semilogarithmic paper, to divide the clearance curves into one or more straight-line segments, and to interpret these segments as representing clearance from separate pulmonary compartments. In the washout curves presented here for normal individuals, where $\log \left(\mathrm{F}_{\mathbf{A}_{\mathbf{N}_{2}}}-\mathrm{FI}_{\mathbf{N}_{2}}\right)$ is plotted against expired volume, no constant number of straight-line segments could be determined. In many instances a single straight line could be drawn through all the nitrogen concentration points for the first few breaths, followed by one or more somewhat less steep straight-line segments. However, the length, slope, and number of these segments varied from one individual to another; hence the attempt to plot straight-line segments to match exactly all observed points was abandoned and instead lines were drawn to fit a majority of the points by inspection. The transition of the initial rapid decline of nitrogen concentration into the later slow decline was also variable from one person to another, but in all subjects took the form of a smooth bend. A convenient end-point for the initial rapid washout phase was arbitrarily chosen as the ventilation point on the curves which coincided with the 1 per cent $\left(F_{A_{N_{2}}}-F_{I_{N_{2}}}\right)$ line. This total observed volume of expired gas is designated $\mathrm{V}_{\mathbf{E}}$ (1 per cent), and the calculated total expired alveolar gas to this point is designated $V_{A}$ (1 per cent).

Figure 2A shows for Group I the mean plot of $V_{E}$ against $F_{A_{N_{2}}}-F_{I_{N_{2}}}$ down to 1 per cent, together with the standard deviation. The mean $\mathrm{V}_{\mathbf{E}}$ ( 1 per cent) is 25.14 liters \pm 5.70 (S. D.), with a coefficient of variation of 22.7 per cent. Figure 2B shows the corresponding relationship for $V_{A}$ (1 per cent). The mean value for $\mathrm{V}_{\mathbf{A}}$ ( 1 per cent) is 16.55 liters \pm 4.46 ( $\mathrm{S}$. D.), with a coefficient of variation of 27 per cent. These data are tabulated in Table III.

The main physiological factor determining nitrogen clearance from the lung during the oxygenbreathing period should, theoretically, be the lung

TABLE III

Initial or steep part of clearance curve-Group I

\begin{tabular}{|c|c|c|c|c|c|c|c|c|}
\hline \multirow{2}{*}{$\begin{array}{c}\mathrm{F}_{\mathbf{A N}_{2}}-\mathrm{F}_{\mathbf{I}_{2}}{ }^{*} \\
(\%)\end{array}$} & \multicolumn{2}{|c|}{$\underset{\text { (liters) }}{\mathrm{VE}^{*}}$} & \multicolumn{2}{|c|}{$\begin{array}{c}\mathrm{VA}_{\text {(iters) }}^{*} \\
\text { (lis }\end{array}$} & \multicolumn{2}{|c|}{ 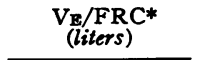 } & \multicolumn{2}{|c|}{$\begin{array}{c}\mathrm{V}_{\mathrm{A}} / \mathrm{FRCR} \mathbf{C}^{*} \\
\text { (liters) }\end{array}$} \\
\hline & Mean & S.D. & Mean & S.D. & Mean & S.D. & Mean & S.D. \\
\hline $\begin{array}{r}60 \\
40 \\
20 \\
10 \\
8 \\
6 \\
4 \\
2 \\
1\end{array}$ & $\begin{array}{r}0.98 \\
2.36 \\
5.24 \\
8.39 \\
9.52 \\
11.00 \\
13.29 \\
18.03 \\
25.14\end{array}$ & $\begin{array}{l}0.66 \\
0.84 \\
1.46 \\
1.74 \\
1.93 \\
2.25 \\
2.78 \\
3.74 \\
5.70\end{array}$ & $\begin{array}{r}0.55 \\
1.55 \\
3.54 \\
5.62 \\
6.35 \\
7.29 \\
8.72 \\
11.80 \\
16.55\end{array}$ & $\begin{array}{l}0.55 \\
0.62 \\
0.98 \\
1.36 \\
1.52 \\
1.77 \\
2.16 \\
2.92 \\
4.46\end{array}$ & $\begin{array}{r}0.42 \\
1.04 \\
2.31 \\
3.70 \\
4.19 \\
4.84 \\
5.84 \\
7.93 \\
10.97\end{array}$ & $\begin{array}{l}0.19 \\
0.26 \\
0.34 \\
0.45 \\
0.48 \\
0.53 \\
0.59 \\
0.82 \\
1.29\end{array}$ & $\begin{array}{l}0.23 \\
0.67 \\
1.53 \\
2.43 \\
2.75 \\
3.15 \\
3.76 \\
5.09 \\
7.08\end{array}$ & $\begin{array}{l}0.18 \\
0.18 \\
0.25 \\
0.30 \\
0.33 \\
0.34 \\
0.41 \\
0.55 \\
0.89\end{array}$ \\
\hline
\end{tabular}

${ }^{*} \mathrm{~F}_{\mathrm{AN}_{2}}-\mathrm{F}_{\mathrm{I}_{\mathrm{N}_{2}}}=$ Per cent $\mathrm{N}_{2}$ in expired gas minus per cent $\mathrm{N}_{2}$ in inspired gas.

$V_{E}=$ Total expired gas volume, or sum of tidal volumes.

$\mathrm{V}_{\mathrm{A}}=$ Alveolar component of $\mathrm{V}_{\mathrm{E}}$.

FRC $=$ Functional residual capacity. 
TABLE IV

Relation of increasing functional residual capacity to ventilation and time required to lower $F_{A_{N_{2}}}-F_{I_{N_{2}}}$ to 1 per cent-Group $I^{*}$

\begin{tabular}{|c|c|c|c|c|c|c|}
\hline FRC & No. & VE $(1 \%) \dagger$ & $V_{A}(1 \%) \dagger$ & $\mathrm{VE}(1 \%) / \mathrm{FRC}+$ & $\mathrm{V}_{\mathrm{A}}(1 \%) / \mathrm{FRC}+$ & T (1\%)† \\
\hline liters & & liters & liters & liters & liters & minutes \\
\hline $\begin{array}{l}1.400-1.799 \\
1.800-2.199 \\
2.200-2.599 \\
2.600-2.999 \\
3.000-3.599\end{array}$ & $\begin{array}{r}4 \\
12 \\
8 \\
4 \\
4\end{array}$ & $\begin{array}{l}19.7 \\
22.6 \\
23.6 \\
31.1 \\
35.7\end{array}$ & $\begin{array}{l}11.6 \\
13.7 \\
16.6 \\
21.5 \\
23.9\end{array}$ & $\begin{array}{r}12.290 \\
11.179 \\
10.055 \\
10.929 \\
-10.954\end{array}$ & $\begin{array}{l}7.300 \\
6.768 \\
7.102 \\
7.581 \\
7.504\end{array}$ & $\begin{array}{l}2.29 \\
2.77 \\
3.21 \\
3.42 \\
4.04\end{array}$ \\
\hline
\end{tabular}

* Mean values given for each subgroup.

† See Tables I and III for terminology.

volume (FRC) to be cleared. The larger the lung volume the greater should be the total ventilation (either expired air volume $\mathrm{V}_{\mathbf{E}}$ or alveolar volume $\mathrm{V}_{\mathbf{A}}$ ) required for clearance, provided the lung is normal and no poorly ventilated spaces exist. It was, therefore, of interest to plot $\mathrm{V}_{\mathbf{E}}$ (1 per cent) and $\mathrm{V}_{\mathbf{A}}$ (1 per cent) as a function of the FRC. This has been done in Figures 3A and 3B, based on Table IV. A linear regression formula for the relationship between the two has been obtained and is given in the figures. The correlation co-
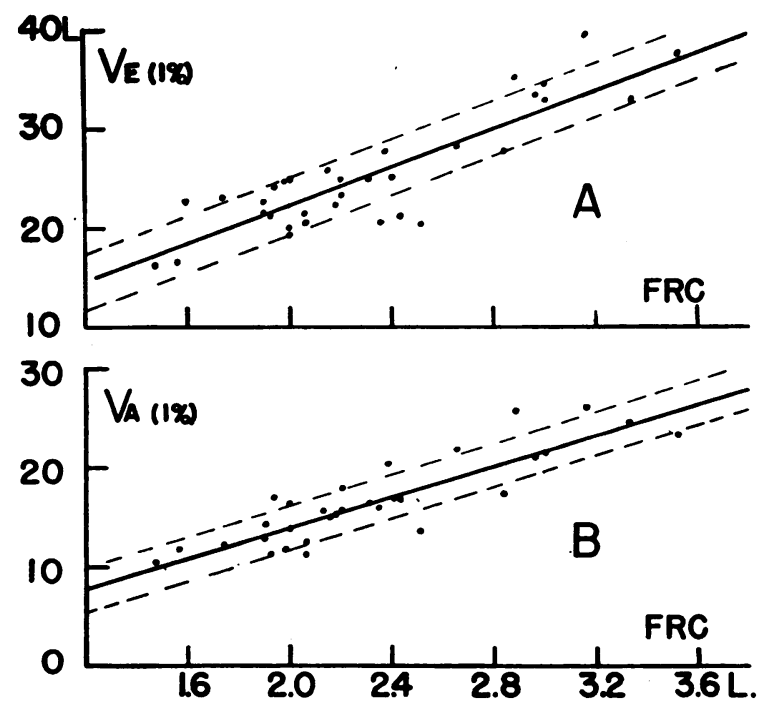

Fig. 3. A-Regression Line Relating Functional Residual Capacity (FRC) and Total Expired Gas Volume to 1 Per Cent Nitrogen; B-Regression Line Relating FRC and Alveolar Ventilation to 1 Per Cent Nitrogen

Heavy center lines represent regression formulae: $V_{B}$ (1 per cent $)=3.05+9.58 \mathrm{FRC}, \pm 2.79$. $\mathrm{V}_{\Delta}$ ( 1 per cent $)$ $=-1.41+7.71 \mathrm{FRC}, \pm 2.27$. Dashed lines represent one standard error of estimate from the regression line. Points represent observed values. efficient for $V_{\mathbf{E}}$ ( 1 per cent) with $F R C$ is 0.872 , and for $\mathrm{V}_{\mathbf{A}}$ (1 per cent) with FRC is 0.745 , which are high coefficients for lung volume variables.

Since the size of the FRC influences strongly the ventilation required to dilute the nitrogen to 1 per cent, the ratios $V_{E}(1$ per cent $) / F R C$ and $V_{\mathbf{A}}$ (1 per cent)/FRC are proposed for the purpose of minimizing this influence and to allow comparison of individuals with different FRC values. These "turnover ratios" may be expressed as the number of complete replacements of FRC by an equivalent volume of expired gas required to reduce the alveolar nitrogen to 1 per cent, or as the fraction of the ventilation of the total FRC to 1 per cent nitrogen which is required to clear one liter of FRC to this level. The results of using these ratios can be seen in Table IV, and in Figure 4, which show the regression of the ratios on FRC and demonstrate clearly that the ratios change little with increase in FRC. The mean value for Group $I$ for $V_{E}$ ( 1 per cent)/FRC is $10.97 \pm$ 1.29 (S. D.), with a coefficient of variation of 11.7 per cent. For $\mathrm{V}_{\mathbf{A}}$ (1 per cent)/FRC the mean value is $7.08 \pm 0.89$ (S. D.), with a coefficient of variation of 12.6 per cent.

The corresponding mean values for the five females at the 1 per cent level are: $\mathrm{V}_{\mathbf{E}}, 19.52 ; \mathrm{V}_{\mathbf{A}}$, $12.22 ; \mathrm{V}_{\mathrm{E}} / \mathrm{FRC}, 11.28$; and $\mathrm{V}_{\mathbf{A}} / \mathrm{FRC}, 7.04$. The close similarity of the turnover ratios to those of the men is to be noted.

In addition to FRC, the efficiency of nitrogen clearance during oxygen-breathing should be influenced by the magnitude of the ratio $V_{\mathbf{A}} / \mathrm{V}_{\mathbf{T}}$ (where $\mathrm{V}_{\mathbf{T}}$ is tidal volume), since it determines what fraction of the tidal volume penetrates into alveolar regions. A plot of $V_{\mathbf{E}}$ (1 per cent) against $V_{\mathbf{A}} / \mathrm{V}_{T}$ reveals no obviously close rela- 

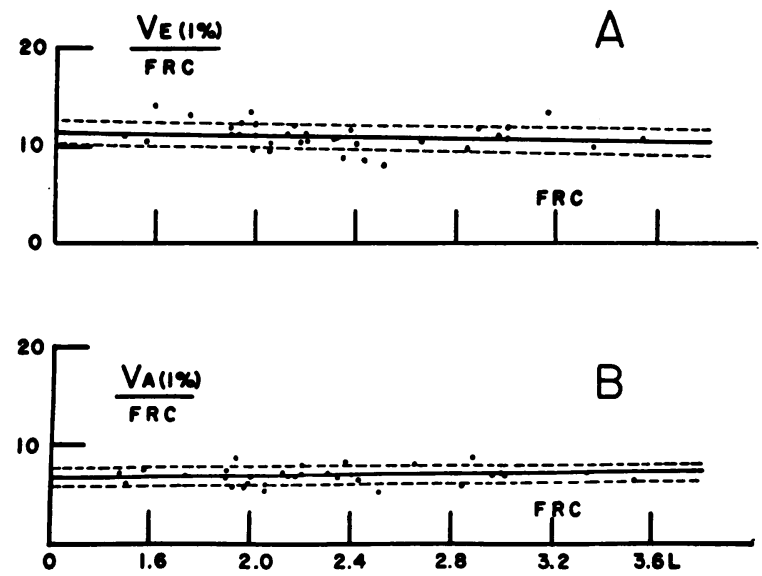

Fig. 4. A-Regression Line Relating Functional Residual Capacity (FRC) and Ve (1 Per Cent)/ FRC; B-Regression Line Relating FRC and VA (1 PER CENT)/FRC

Heavy center lines represent regression formulae: $\mathrm{VE}$ ( 1 per cent $) / F R C=12.024-0.455 \mathrm{FRC}, \pm 1.224$; VA ( 1 per cent) $/ \mathrm{FRC}=6.546+0.23 \mathrm{FRC}, \pm 0.872$. Dashed lines represent one standard error of estimate from the regression line. Points represent observed values.

tionship, indicating that in these normal subjects variation in dead space volumes had no apparent effect on the washout curves. This has been noted previously (7).

The mean time required for $\mathrm{F}_{\mathrm{A}_{\mathrm{N}_{2}}}-\mathrm{F}_{\mathrm{I}_{2}}$ to reach 1 per cent in Group $I$ is 3.06 minutes \pm 0.86 (S. D.), with a coefficient of variation of 28.2 per cent (Figure 5). Darling, Cournand, Mansfield, and Richards (2) found that the 1 per cent level was reached in 3.5 to 4 minutes. Luft, Roorbach, and MacQuigg (13) reported that healthy subjects reached " 1 per cent, or less" in three to six minutes. The time required to reach 1 per cent depends on ventilation rate, on the size of dead space volume and tidal volume, and the ratio of one to the other, and, of course, on any impairment of intrapulmonary mixing. A hyperventilator will reach the 1 per cent level in a shorter time than a person with lesser ventilation. The advantage of expressing nitrogen clearance as a function of expired volume rather than as a function of time is that it excludes the variable factor of ventilation rate.

Apparently the initial rapid decline in expired nitrogen concentration represents the clearance of well-ventilated areas. This is followed by a flattening out of the curve of nitrogen dilution in

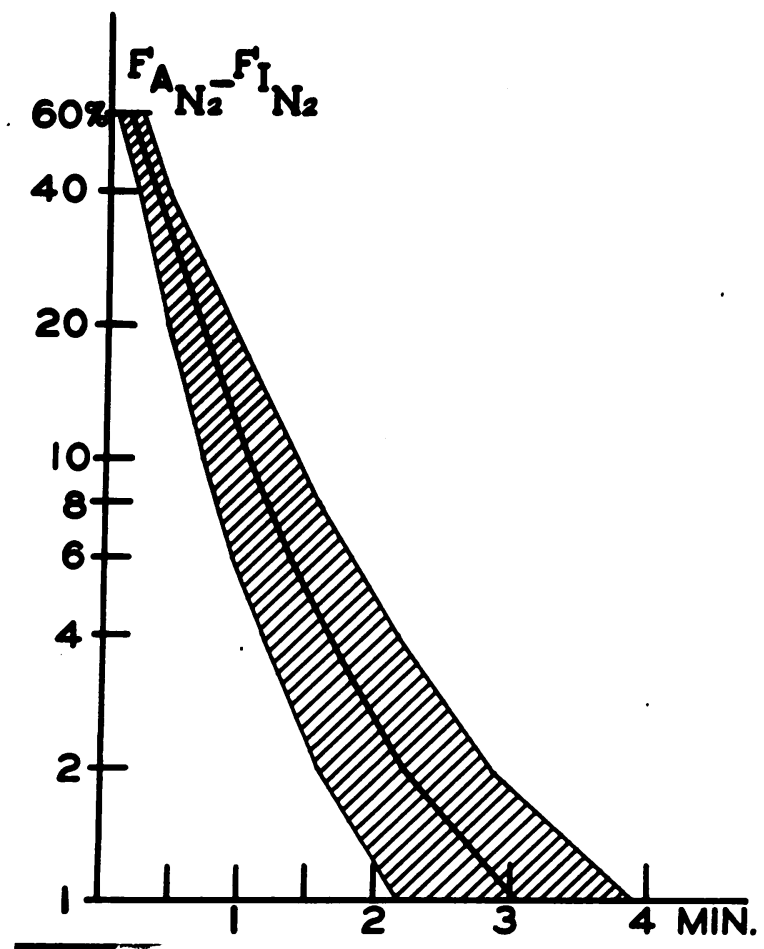

Fig. 5. Group I-Time ReQuired to Reduce EndExpired Nitrogen Concentration to 1 Per Cent, During Oxygen Breathing

Center line represents mean value for 33 subjects. Cross-hatching represents one standard deviation from the mean.

an asymptotic fashion. Roughly, the second half of the seven minute period of oxygen breathing is characterized by a slow decline of end-expired nitrogen levels. The mean values for $\mathrm{F}_{\mathrm{A}_{\mathrm{N}_{2}}}-\mathrm{F}_{\mathrm{I}_{\mathrm{N}_{2}}}$ at the end of the fourth minute and at the end of the seventh minute, and the difference between

TABLE V

Behavior of nitrogen decline in last three minutes of washoutGroups I, II, and III combined; 49 subjects

\begin{tabular}{|c|c|c|c|c|c|}
\hline & $\begin{array}{c}\mathrm{F}_{\mathbf{A N}_{N_{2}}-F_{\mathbf{I}_{N_{2}}}{ }^{*}} \\
\text { at 4th } \\
\text { minute } \\
\%\end{array}$ & $\begin{array}{c}\mathrm{F}_{\mathbf{A N}_{N_{2}}-F_{\mathbf{I}_{N_{2}}}}{ }^{*} \\
\text { at } 7 \text { th } \\
\text { minute } \\
\%\end{array}$ & $\begin{array}{l}\Delta_{\%}^{\prime} \dagger \\
\%\end{array}$ & $\begin{array}{c}\mathrm{F}_{\mathbf{A}_{\mathbf{N}}}-\mathrm{F}_{\mathbf{I}_{\mathbf{N}_{2}}}{ }^{*} \\
\text { final } \\
\text { forced } \\
\text { expiration } \\
\%\end{array}$ & $\underset{\%}{\Delta^{\prime \prime} \ddagger}$ \\
\hline $\begin{array}{l}\text { Mean } \\
\text { S. D. }\end{array}$ & $\begin{array}{l}0.72 \\
0.34\end{array}$ & $\begin{array}{l}0.47 \\
0.16\end{array}$ & $\begin{array}{l}0.25 \\
0.29\end{array}$ & $\begin{array}{l}0.53 \\
0.18\end{array}$ & $\begin{array}{l}0.06 \\
0.07\end{array}$ \\
\hline
\end{tabular}

${ }^{*} \mathrm{~F}_{\mathrm{AN}_{2}}-\mathrm{F}_{\mathrm{I}_{\mathrm{N}_{2}}}=$ Per cent $\mathrm{N}_{2}$ in expired gas minus per cent $\mathrm{N}_{2}$ in inspired gas.

t $\Delta^{\prime}=$ Difference between nitrogen concentrations at end of fourth and seventh minutes.

$\ddagger \Delta^{\prime \prime}=$ Difference between nitrogen concentrations produced by final forced expiration and the preceding ordinary breath at end of seventh minute. 


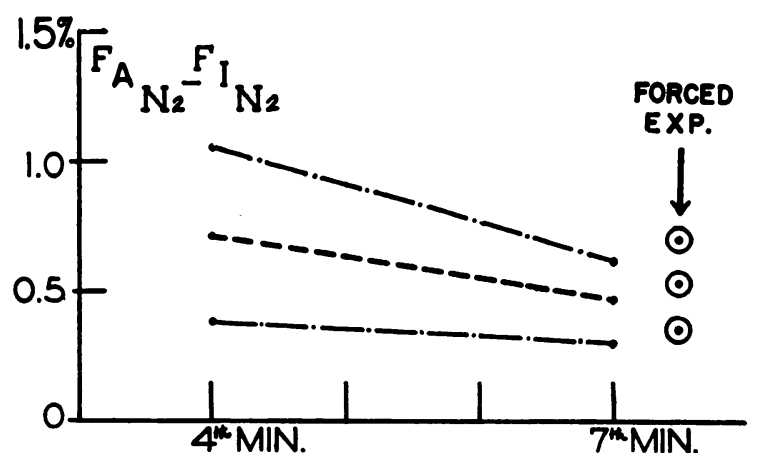

Fig. 6. Schematic Representation of Decline of Nitrogen Concentration From Fourth to Seventh Minute of Oxygen Breathing, Followed by a MaxiMUM Expiration-Forty-Nine Subjects

Heavy dashed center line represents mean value. Outer dashed lines represent one standard deviation from the mean.

these two values, are shown in Table $\mathrm{V}$ and in Figure 6.

The final characteristic of these normal washout curves is the small change in nitrogen concentration produced by a maximal forced expiration at the conclusion of seven minutes of quiet breathing of oxygen. The mean end-expired nitrogen concentration in the terminal forced expiration reached by 49 subjects is 0.53 per cent \pm 0.18 (S. D.), expressed at $\mathrm{FA}_{\mathrm{N}_{2}}-\mathrm{F}_{\mathrm{I}_{2}}$. The mean increment between this and the last preceding ordinary breath is 0.06 per cent \pm 0.07 (S. D.) as shown in Table V. Sixteen out of 49 subjects had no detectable rise; 20 additional subjects had a rise not exceeding 0.1 per cent above the last preceding ordinary breath. Ninety-four per cent of the sub-

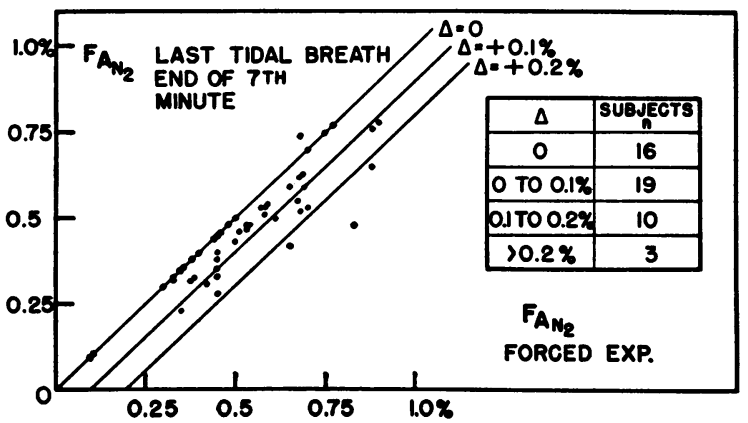

Fig. 7. Difference Between End-Tidal Nitrogen Concentration of Last Tidal Breath at End of Seven Minutes Oxygen Breathing and the Nitrogen Concentration Produced by the Terminal Forced Expiration-Forty-Nine SubjeCts jects had no increment greater than 0.2 per cent nitrogen (Figure 7). The greatest increases produced by the forced expirations were, respectively, 0.23 per cent in each of two women, and 0.35 per cent in one man. No adequate explanation for these three aberrant values could be found on review either of the experimental data or of the health records and chest radiographs of these students.

\section{DISCUSSION}

It is obvious that the initial or rapidly declining part of the nitrogen displacement curve depicts a well-ventilated space or series of spaces. The later, slowly falling, portions of the curve represent probably a combination of nitrogen displacement from poorly-ventilated alveolar regions and the diffusion of nitrogen from the tissues via the pulmonary circulation into the alveolar gas where the nitrogen tension is lower. How much each of these factors enter into the situation is unknown. The small terminal rise in nitrogen produced by forced expiration would indicate that complete intrapulmonary mixing of oxygen and nitrogen may not occur even after seven minutes in normal persons. This finding confirms the conclusions of Fowler, Cornish, and Kety $(7,26)$.

Calculation of the ventilation in terms of alveolar ventilation involves assumptions not only of constancy of tidal volumes, dead space, and FRC, but also of the validity of a single, forced expiration sample as a true representation of alveolar carbon dioxide. It will be noted in Table II that in the Group I cases the scatter of $V_{\mathbf{A}}$ ( 1 per cent) leads to a coefficient of variation of 27 per cent. The above mentioned variables may be partially circumvented if analyses are limited to $\mathrm{V}_{\mathbf{E}}$ (1 per cent), where the coefficient of variation is 22.7 per cent. Using the ratio $\mathrm{V}_{\mathbf{E}}$ (1 per cent)/FRC reduces the scatter still further to a coefficient of variation of 11.7 per cent. Moreover, it allows comparison among individuals with different lung sizes and rates of ventilation. Therefore, the ratio can be considered as a useful index of intrapulmonary mixing. Expressing this ratio as $\mathrm{V}_{\mathbf{A}}$ (1 per cent)/FRC does not reduce scatter (coefficient of variation, 12.6 per cent).

A second useful and easily determined index of intrapulmonary mixing is the presence and size of the increment in nitrogen produced by the final 
forced expiration. This gives, at a glance, a measure of uniformity of ventilation and indicates the patency of airway communication with poorly ventilated spaces which can be partially emptied by forceful expiration (27). The magnitude of this rise in normal subjects has not been given much attention by previous investigators in connection with prolonged nitrogen washout periods, although Fowler has studied this point by the single-breath nitrogen dilution technique (26).

Luft, Roorbach, and MacQuigg (13), whose experimental procedure resembled that reported here, terminated their nitrogen washout tests when the end-expired nitrogen reached 1.0 per cent or 1.4 per cent, without finishing with a forced expiration. These investigators implied that continued fall in nitrogen below 1 per cent can be attributed to diffusion of the gas from the body tissues. They did not correct, apparently, for inspired nitrogen in the cylinder oxygen. They emphasized the concept of "clearance equivalent," which has been adopted here; namely, the total ventilation to the end-point as the number of replacements of FRC (or the amount of ventilation to clear one volume equivalent to FRC to 1 per cent). This expression eliminates such variable factors as respiratory rate, functional residual capacity, and alveolar ventilation, and reduces total ventilation (cumulative expired volume) to figures which can be used to compare one individual to another. For 25 normal males and 12 normal females, in the seated position, ranging in age from 12 to 64 years, Luft and associates found the mean ventilation to 1 per cent $\left[\mathrm{V}_{\mathbf{E}}\right.$ (1 per cent) in our terminology] to be 44.7 liters in the males and 37.8 liters in the females. Their mean "clearance equivalents" $\left[\mathrm{V}_{\mathbf{E}}(1\right.$ per cent $) / \mathrm{FRC}$ in our terminology] were 13.3 for the males and 13.9 for the females. These values are greater than those in the present report probably because the initial FRC of Luft's subjects was larger as a result of the seated posture, and because of lack of correction for inspired nitrogen.

\section{SUMMARY}

1. A method for studying the course of intrapulmonary nitrogen dilution during oxygen breathing by means of a nitrogen meter was incorporated into a well-known procedure for open circuit measurement of functional residual capacity. This method is simple enough to be used clinically.

2. In a group of fifty normal recumbent young adults the course of the nitrogen dilution was followed for seven minutes, and terminated by a forced expiration.

3. Values are given for clearance ventilation to 1 per cent end-expired nitrogen (minus inspired nitrogen), expressed both for total ventilation and alveolar ventilation. These values were found to depend largely upon the size of the functional residual capacity. Clearance equivalent ratios are given which allow comparisons among individuals with different functional residual capacities.

4. The characteristics of the latter half of the washout curves, after the 1 per cent level of nitrogen has been passed, have been investigated with particular emphasis on the usefulness of the final forced expiration.

5. The procedure is a practical method for detecting the presence of uneven alveolar ventilation.

\section{ACKNOWLEDGMENT}

The authors are indebted to Dr. David Salkin for helpful criticism and support.

\section{REFERENCES}

1. Rauwerda, P. E. Unequal ventilation of different parts of the lung and the determination of cardiac output. Thesis, Groningen, Groningen Univ., 1946.

2. Darling, R. C., Cournand, A., Mansfield, J. S., and Richards, D. W., Jr. Studies on the intrapulmonary mixture of gases. I. Nitrogen elimination from blood and body tissues during high oxygen breathing. J. clin. Invest. 1940, 19, 591.

3. Cournand, A., Baldwin, E. DeF., Darling, R. C., and Richards, D. W., Jr. Studies on intrapulmonary mixture of gases. IV. The significance of the pulmonary emptying rate and a simplified open circuit measurement of residual air. J. clin. Invest. 1941, 20, 681.

4. Darling, R. C., Cournand, A., and Richards, D. W., Jr. Studies on intrapulmonary mixture of gases. V. Forms of inadequate ventilation in normal and emphysematous lungs, analyzed by means of breathing pure oxygen. J. clin. Invest. 1944, 23, 55.

5. Lilly, J. C. Studies on the mixing of gases within the respiratory system with a new type nitrogen meter. Fed. Proc. 1946, 5, 64.

6. Robertson, J. S., Siri, W. E., and Jones, H. B. Lung ventilation patterns determined by analysis of 
nitrogen elimination rates; use of the mass spectrometer as a continuous gas analyzer. J. clin. Invest. 1950, 29, 577.

7. Fowler, W. S., Cornish, E. R., Jr., and Kety, S. S. Lung function studies. VIII. Analysis of alveolar ventilation by pulmonary $\mathrm{N}_{2}$ clearance curves. J. clin. Invest. 1952, 31, 40.

8. Bateman, J. B. Studies of lung volume and intrapulmonary mixing. Nitrogen clearance curves: Apparent respiratory dead space and its significance. J. appl. Physiol. 1950, 3, 143.

9. Boothby, W. M., Lundin, G., and Helmholz, H. F., Jr. A gaseous nitrogen elimination test to determine pulmonary efficiency. Proc. Soc. exp. Biol. (N. Y.) 1948, 67, 558.

10. Wolfe, W. A., and Carlson, L. D. Studies of pulmonary capacity and mixing with the $\mathrm{N}_{2}$ meter. J. clin. Invest. 1950, 29, 1568.

11. Colldahl, H., and Lundin, G. Ventilatory studies of the lungs in asthma. Acta allerg. (Kbh.) 1952, 5, 37.

12. Becklake, M. B. New index of intrapulmonary mixture of inspired air. Thorax 1952, 7, 111.

13. Luft, U. C., Roorbach, E. H., and MacQuigg, R. E. Pulmonary nitrogen clearance as a criterion of ventilatory efficiency. Amer. Rev. Tuberc. 1955, $72,465$.

14. Peters, J. P., and Van Slyke, D. D. Quantitative Clinical Chemistry, Volume II, Methods. Baltimore, The Williams \& Wilkins Co., 1932.

15. Scholander, P. F. Analyzer for accurate estimation of respiratory gases in one-half cubic centimeter samples. J. biol. Chem. 1947, 167, 235.

16. Cournand, A., Yarmush, I. G., and Riley, R. L. Influence of body size on gaseous nitrogen elimination during high oxygen breathing. Proc. Soc. exp. Biol. (N. Y.) 1941, 48, 280.
17. Methods in Medical Research, J. H. Comroe, Jr., Ed. Chicago, Year Book Publishers, 1950, vol. 2, p. 200.

18. Standardization of definitions and symbols in respiratory physiology. Fed. Proc. 1950, 9, 602.

19. Kaltreider, N. L., Fray, W. W., and Hyde, H. V. Z. The effect of age on the total pulmonary capacity and its subdivisions. Amer. Rev. Tuberc. 1938, 37, 662.

20. Needham, C. D., Rogan, M. C., and McDonald, I. Normal standards for lung volumes, intrapulmonary gas-mixing, and maximum breathing capacity. Thorax 1954, 9, 313.

21. Whitfield, A. G. W., Waterhouse, J. A. H., and Arnott, W. M. The total lung volume and its subdivisions. A study in physiological norms. I. Basic data. Brit. J. soc. Med. 1950, 4, 1.

22. Whitfield, A. G. W., Waterhouse, J. A. H., and Arnott, W. M. The total lung volume and its subdivisions. A study in physiological norms. III. Correlation with other anthropometric data. Brit. J. soc. Med. 1950, 4, 113.

23. Bateman, J. B. Studies of lung capacities and intrapulmonary mixing; normal lung capacities. J. appl. Physiol. 1950, 3, 133.

24. Gray, J. S., Grodins, F. S., and Carter, E. T. Alveolar and total ventilation and the dead space problem. J. appl. Physiol. 1956, 9, 307.

25. Rossier, P. H., and Bühlmann, A. The respiratory dead space. Physiol. Rev. 1955, 35, 860.

26. Fowler, W. S. Lung function studies. III. Uneven pulmonary ventilation in normal subjects and in patients with pulmonary disease. J. appl. Physiol. 1949, 2, 283.

27. Bedell, G. N., Marshall, R., DuBois, A. B., and Comroe, J. H., Jr. Plethysmographic determination of the volume of gas trapped in the lungs. J. clin. Invest. 1956, 35, 664. 